Franklin's and Bonaparte's Gulls, vireos and the many Fringillidae that occur here, provide examples. The provincial check-list will suggest many others.

The book is well written in the author's usual clear readable style. It is free from professional jargon and should be readily understood by the informed layman. Moreover, Dr. Lack has simplified the presentation by relegating the details of the ecological separation of the species discussed to Appendices.-William J. Maher, Saskatoon.

\title{
Letters and Notes
}

\section{IN DEFENCE OF THE COYOTE}

Some time ago a notice was posted by the Rural Municipality of Rocanville warning that about 10 coyote poison baits had been set out at various points. A protest to the Reeve brought the explanation that "it was the will of the ratepayers at the annual meeting." Knowing the usual small attendance at such meetings, I doubt whether such an inhumane decision would reflect the opinion of the majority of the community.

Enclosed is a letter I recently received from Alvin Griswold of Spy Hill. Alvin has spent his life in the Qu'Appelle Valley country and as a hunter and trapper in earlier years he can speak without bias.-E. Symons, Rocanville, Sask.

I thought it best to say a few words in defence of the coyote. There have been parts of the country where the coyote has been wiped out; two years later the fields have been overrun with mice. We had that here years ago and the damage could not be counted.

The coyote is the key to the balance of Nature in this park country. For instance, the coyote is the world's best mouser. It knows no equal. I have watched the coyote walking over the snow, ear to the snow. It can hear the mice digging tunnels under the snow. The coyote will leap up, come down with four feet tight together and crush the tunnel, dig in with its mouth and catch the mouse, throw the mouse in the air and catch it again. The coyote often catches as many as 30 mice a day.
Coyotes are blamed for killing a lot of sheep when the sheep have actually been killed by dogs. It is true that the coyote will take chicken; I can't blame him, I like chicken myself! But most people fence chicken in nowadays. If they don't, they should.

I hate poison and don't want to see it used at all. I have of ten seen chickadees, woodpeckers and nuthatches at the poisoned bait and wonder how many dead birds result from such poisoning.-Alvin Griswold, Spy Hill, Sask.

\section{EAGLES SLAUGHTERED}

On August 3, 1971, the radio carried an almost incredible report that some 800 eagles had been shot from helicopters in Wyoming. The accuracy of the report has been established, however, with the publication of a detailed article in the September, 1971 issue of Audubon. Granted immunity from prosecution, the helicopter pilot, J. O. Vogan, testified before Senator McGee, chairman of the subcommittee on Agriculture, Environmental and Consumer Protection to the effect that wealthy landowners and sheep breeders, in defiance of federal and state laws, were indeed hiring people to slaughter eagles, coyotes, foxes, bobcats and even some antelope, deer, elk and Canada geese.

Since the man responsible for the death of most of the 800 eagles recorded by Vogan is the father-in-law of the rancher charged with the illegal killing and baiting of antelope (Blue Jay, 29(3):p. 157, September 1971) which caused the death of at least 22 
eagles, it can be assumed that that operation was aimed at eagles as well as at coyotes.

It is to be hoped that Canadian laws will soon prevent the use of poisoned baits and the shooting or harassing of animals from any kind of vehicle. If you know of illegal acts which have been committed in your area, please write to the Blue Jay editor.-Editor, Box 1321, Regina.

\section{FRIENDSHIPS}

Attending a Natural History Society Summer Meeting can result in the formation of friendships which will provide many hours of interesting discussion on hobbies and travel. Such has been our experience anyway.

Several years ago at the meeting at Fort Qu'A ppelle we met Mr. Edgar W. Sullivan of Dundurn. A common interest in Indian artifacts led to later correspondence and visits from $\mathrm{Mr}$. Sullivan and his kindly companion of many years, visits which have given our family idea-filled hours of enjoyment.

From Mr. Sullivan's vehicle may come boxes of beautiful slides-flowers, travel, animals and history. Next will come trays of beautifully polished rocks, collected from many places. Hand-made cribbage boards of inlaid design and made from local woods share the space with displays of bridle bits from bygone years.

A coin collection or display cases of artifacts may also appear, depending on whom Mr. Sullivan is visiting. Among other things, licence plates and fruit jars, samples of barbed wire or match books, seashells or wood samples may be brought forth. A good camera accompanies Mr. Sullivan everywhere, plus the gift of making his travels come alive for his listeners.

All this would be enough to keep a young person very busy kut when one realizes that this highly entertaining couple are 84 and 89 years of age, one marvels at the zest and good health that they possess. If younger people would take up even one hobby, they would help ensure themselves of many hours of shared interests in later years, with resulting benefit to their health and morale.

We have been able to attend only those summer meetings held at Batoche, Fort Qu'Appelle, and Indian Head, but have thoroughly enjoyed all three and the friendships formed at them. Certainly, our friendship with Mr. Sulliyan has made our lives richer.-Hazel Paton, Oxbow.

\section{SIGHTING OF A SWALLOW-TAILED KITE AT TISDALE, SASKATCHEWAN,}

On a Saturday morning in early April 1921, my late brother Maurice and I were walking across our farm ( $3 \frac{1 / 2}{1}$ miles northwest of Tisdale) heading for the Doghide River, a favourite area of ours for bird watching. Suddenly we both spotted the strangest bird we had ever seen, flying towards us. As we watched in amazement, a bird we recognized as a Swallow-tailed Kite passed in front of us, less than 100 feet away and no more than 50 feet high. It was heading into a strong northwest wind, and the graceful flight of this black and white bird with its long, pointed wings and deeply forked tail will never be forgotten.-Stanley J. Street, 3724 Happy Valley Road, RR1, Victoria, B.C.

Editor's Note: This species is listed as an accidental straggler for Saskatchewan on the basis of three sight records over a period of 35 years' observations by George Lang as follows: "one at Fort Qu'Appelle, May 24, 1890, one near Lake Katepwa, June 9, 1898, and one near Regina, June 20, 1906" (Mitchell, Catalogue of the birds of Saskatchewan, 1924:108). There is also a record of an observation in Regina in the spring of 1955 by Elmer Fox. Godfrey (The birds of Canada, 1966:86) regards it as accidental in Canada, noting single specimens for Ontario and Nova Scotia (prior to 1907, 1905) and "unconfirmed additional (mostly old) sight records for Saskatchewan, Manitoba and Ontario. Formerly when more numerous within its normal range it probably strayed 
to Canada more frequently than it does today."

C. Stuart Houston (pers. corres., September 17, 1971) commented on this belated record, which is not mentioned in Maurice Street's publications, as follows: "Maurice was a meticulous record-keeper, but did not begin keeping his records until 1922, the year after the purported sighting of the Kite. He published only those records for which he had a date in his notebooks, and he published only records for species already on the Saskatchewan list, validated by a specimen .... This sighting was just outside the 30 mile radius used for his first mimeographed publication: A list of the birds of Nipawin, Saskatchewan, Cont. No. 2, Yorkton, Nat. Hist. Soc., 1943. It was well outside the 20 -mile radius generally used for Nipawin records in Birds of the Saskatchewan River, Carlton to Cumberland (Houston and Street, 1959) . . . . It was, of course, Maurice's older brother Stan who initiated Maurice into the habit of careful birdwatching, with considerable encouragement from $\mathrm{E}$. W. Van Blaricom, then a lawyer in Tisdale. My guess is that the record is valid ...."

\section{OWL BANDING}

On the evening of May 22, 1971, Dr. S. Houston, Arnold Nijssen and Bryan Stepaniuk came to band the young Great Horned Owls in our district. Four of us joined them and between $6: 00$ and $9: 30$ p.m. we visited seven nests and banded 11 young owls. Three of the young owls jumped from their nests when the climber was part way up the tree. They were banded and sent back up to their nests by a large string converted into an elevator operation. One nest had fallen down and the two young were found at the base of the tree. They were banded and placed part way up a slanting tree. One young which had already left its nest was found on a brush pile. Arnold Nijssen caught it and after it was banded it was returned to the brush pile. One of the seven nests was empty; evidently the young birds had already deserted the nest. None of the nests contained more than two young.

Next morning we were up early and visited four nests and banded six young before breakfast. Two of the nests contained two young each and two contained only one. After a delicious breakfast prepared by my mother we set out again. We visited one more nest in our district and banded two more Great Horned Owls, then we went to the Crystal Springs area.

In the Crystal Springs area we visited six nests and banded 14 young owls. One nest had three young and one contained four. The four young all left the nest as the tree was being climbed. They were banded but not sent up on the string elevator, as two other young were, because they were big and ready to leave the nest. The parent owls at one nest were really angry and one of them left its claw marks on Dr. Houston's shoulder.

This banding trip was very enjoyable. I was chief pellet collector. The pellets, which are found under each nest, are the regurgitated remains of animals that the owls cannot digest. The pellets contain fur and bones and they can be analysed to see what the owls have eaten and whether the food changes from year to year in the same area.

I am looking forward to next year's banding expedition in this district and am wondering how many young there will be in each nest in 1972.-Condensed from a letter from Rosemary Nemeth, Junior Naturalist, Yellow Creek, Saskatchewan.

\section{SASKATCHEWAN CHRISTMAS BIRD COUNT 1971}

List the number of each bird species seen on the One Best Day from Tuesday, December 21, 1971 through Sunday, January 2 , 1972. In addition, list other species observed during the above dates. See March 1971 Blue Jay for other details. Send reports as soon as possible to Mrs. Mary Houston, 863 University Drive, Saskatoon. 


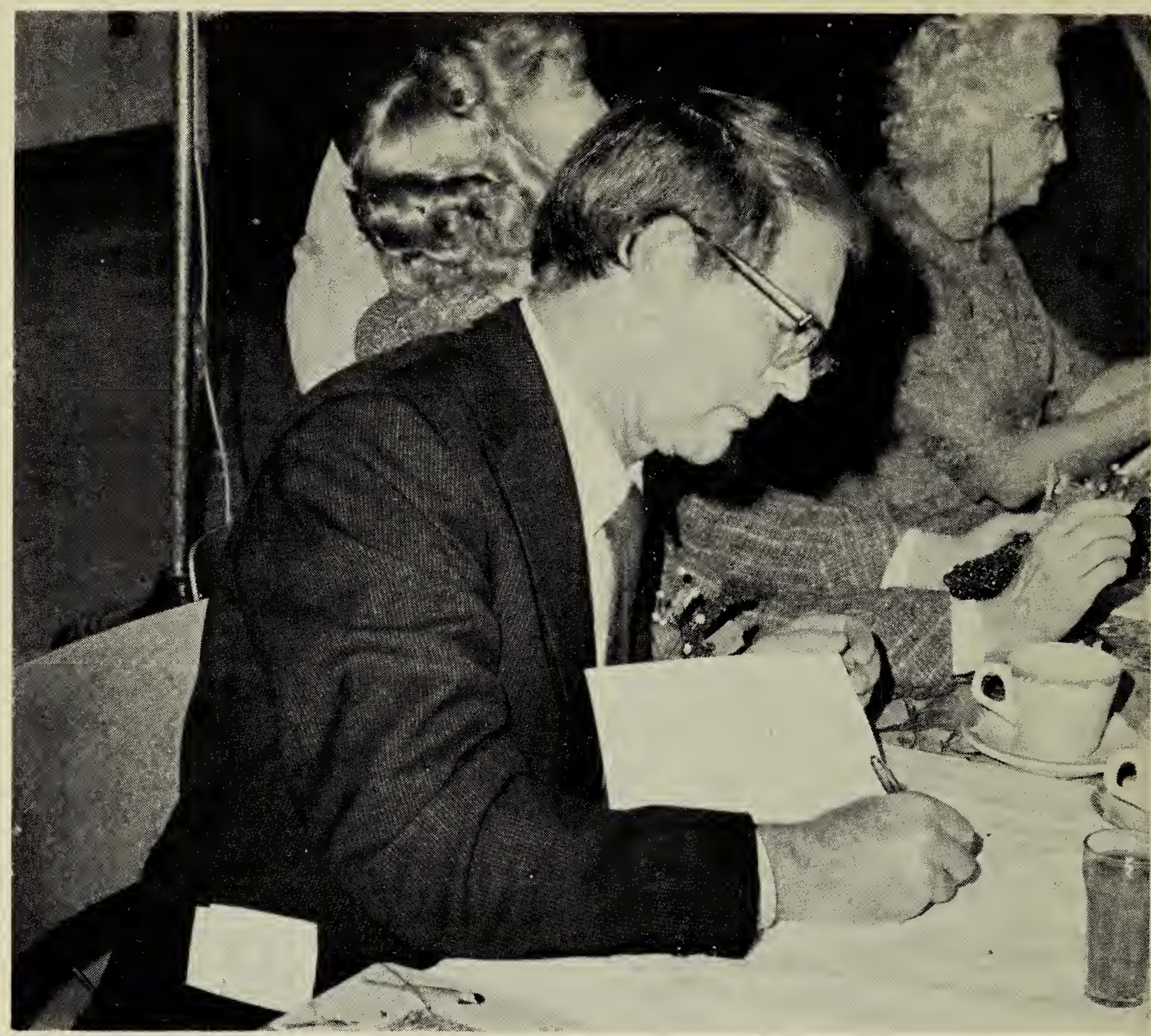

Photo by Gary Seib

Robert W. Nero autographing a copy of his new book Birds of Moose Mountain, Saskatchewan at the annual banquet, Moose Jaw, October 16, 1971.

\section{NEW BOOK PUBLISHED}

\section{BIRDS OF MOOSE MOUNTAIN} SASKATCHEWAN. 1971. By Robert W. Nero and M. Ross Lein, Sask. Nat. Hist. Soc. Special Publication No. 7, 56 pp. $\$ 2.00$.

This attractive booklet, which will be reviewed in the next Blue Jay, was published just in time for the annual meeting in Moose Jaw and in lots of time for purchase as a Christmas gift for anyune interested in Saskatchewan birds. All seven special publications may be obtained from the Blue Jay Bookshop, Box 1121, Regina. Details for the earlier publications are as follows:
No. 1. A guide to Saskatchewan mammals. By W. Harvey Beck. 1958. 52 pages. 50 cents.

No. 2. The birds of the Saskatchewan River, Carlton to Cumberland. By C. Stuart Houston and Maurice G. Street. 1959. 205 pages. $\$ 1.50$.

No. 3. Birds of Regina. By Margaret Belcher. 1961. 76 pages. $\$ 1.00$.

No. 4. The Blue Jay Index, 19421960. By Joyce Deutscher. 1962. 36 pages. $\$ 2.00$.

No. 5. Birds of the Lake Athabasca region, Saskatchewan. By Robert W. Nero. 1963. 143 pages. \$2.50.

No. 6. The birds of northeastern Saskatchewan. By Robert W. Nero. 1967. $\$ 2.00$. 